\title{
What does Indian Premier League pay to India?
}

\author{
Dr. Shankar $\mathrm{R}^{1}$, Dr. Nanda Gopal. $\mathrm{L}^{2}$ \\ \{sr.hum@psgtech.ac.in ${ }^{1}$,lng.hum@psgtech.ac.in ${ }^{2}$ \} \\ Assistant Professor, Department of Humanities, PSG College of Technology, Coimbatore. ${ }^{1,2}$
}

\begin{abstract}
Cricket is more than simply a sport in India; it is a religion with a sizable following. Cricket has a global fan base of more than a billion people, with the Indian subcontinent accounting for nearly all of them. It is quite normal that children and adults can be seen playing street cricket on India's streets and narrow footpaths. To meet out the expectations of citizens of cricket crazy nation, the Board of Control for Cricket in India (BCCI) determined to expand the game to reap benefit through the introduction of intra country cricket league in 2007, following the T20 World Cup victory. In 2008, the Indian Premier League (IPL) was born as a result of this. It quickly became BCCI's most lucrative annual sporting event just a few years after its inception. The presentation will provide an overview of the operations, revenue, and contribution of IPL to the Indian economy.
\end{abstract}

Keywords: Cricket, Board of Control for Cricket in India (BCCI), Indian Premier League.

\section{Introduction Genesis of IPL}

Following India's triumph at 2007 T20 World Cup, the BCCI declared the Indian Premier League as a franchise-based Twenty 20 cricket competition to replace the Indian Cricket League, which was deemed a rebel league by the BCCI and was later suspended in 2007 and folded out in 2008. The first season held in April 2008 in New Delhi, with a "high-profile ceremony." Lalit Modi, who pioneered the IPL, outlined the rules of the tournament. With clubs representing the major cities of the country, the league had an eight-team system, including Mumbai, Chennai, Kolkata and Delhi alongside others. On January 24, 2008, an auction was held to determine the new league's owners. The franchises had an initial base price of around $\$ 400$ million, and ended up traded for a sum of $\$ 723.59$ million.

\section{Literature Review}

According to Amit Gupta in 2009, IPL is a big step to realign the international sports. He goes on to say that if the IPL and other similar sporting projects succeed in non-western countries, the West's sporting hegemony will be challenged, and these countries will have a greater say in where and how the game is played. Shashi Kadapa, According to reports from 2013, the IPL has a market value of more than $\$ 4$ billion. The high-profile, glamour-filled franchisee-owned cricketing event has also seen record amounts of money paid out in franchisee fees, player fees, and advertising revenue, as well as match-fixing controversies. 
According to Umar Rashi Dar, IPL serves as a great promoter of India's cultural heritage to the rest of the world. He goes on to say that it is undoubtedly a billion-dollar infant, delivering massive income to franchisees while also contributing significantly to India's GDP.

\section{Brand value}

The tournament's value has risen exponentially from 2016 to 2018. The IPL was valued in 2016 at $\$ 4.16$ billion which was grown to $\$ 5.3$ billion and $\$ 6.13$ billion in the successive years. The broadcast deal was signed with Star India Private Limited, because the event was proposed to be broadcasted on eight different regional languages, according to a Duff \& Phelps report, was one of the contributing factors in the Indian Premier League's rapid growth in value. The league has its benefit to the players, various clubs involved, various stakeholders, and India as a whole economically. Due to the corona virus pandemic, 2020 was a difficult year, with economic hardship and uncertainty. The sports economy was not immune to the crisis, and the pandemic caused several tournaments to be delayed or cancelled during the year. The IPL was also affected by the pandemic, with the overall brand value, individual franchisees seeing their brand prices plummet. Before it could be held in the UAE, the IPL 2020 had to be postponed. The tournament went off without a hitch, but the pandemic took a toll on the teams' brand image. In actuality, the IPL's trademark value has dropped for perhaps the first time in six years.

Table 1: IPL Franchises Brand Value

\begin{tabular}{|l|l|l|l|}
\hline \multirow{2}{*}{ Teams } & \multicolumn{2}{l|}{$\begin{array}{l}\text { Brand value } \\
\text { (INR crores })\end{array}$} & \multirow{2}{*}{ \% Change } \\
\cline { 2 - 3 } & $\mathbf{2 0 2 0}$ & $\mathbf{2 0 1 9}$ & \\
\hline Mumbai Indians & 761 & 809 & $-5.9 \%$ \\
\hline Chennai Super Kings & 611 & 732 & $-16.5 \%$ \\
\hline$\underline{\text { Kolkata Knight Riders }}$ & 543 & 629 & $-13.7 \%$ \\
\hline$\underline{\text { Royal Challengers Bangalore }}$ & 536 & 595 & $-9.9 \%$ \\
\hline$\underline{\text { Sunrisers Hyderabad }}$ & 442 & 483 & $-8.5 \%$ \\
\hline$\underline{\text { Delhi Capitals }}$ & 370 & 374 & $-1.0 \%$ \\
\hline$\underline{\text { Punjab Kings }}$ & 318 & 358 & $-11.3 \%$ \\
\hline$\underline{\text { Rajasthan Royals }}$ & 249 & 271 & $-8.1 \%$ \\
\hline
\end{tabular}

Source: Duff \& Phelps IPL Brand Valuation Report

The IPL ecosystem value was found declined by 3.6 percent in 2020 with the total value being INR 45,800 crores. For the fifth year in a row, the Mumbai Indians (MI) was ranked first in the brand rankings, with a brand image of INR 761 crores, down $5.9 \%$ from the previous year. KKR (Kolkata Knight Riders) and CSK (Chennai Super Kings) were rated second and third, respectively. CSK's value plummeted by 16.5 percent to INR 611 crore in 2020, while KKR's value dropped by 13.7 percent to INR 543 crore. The Delhi Capitals (DC) suffered the tiny impact amongst all, with their value dropping by just $1 \%$ with the total value of INR 370 cores from INR 374 crores. 
Chart 1: Brand value of IPL Franchises

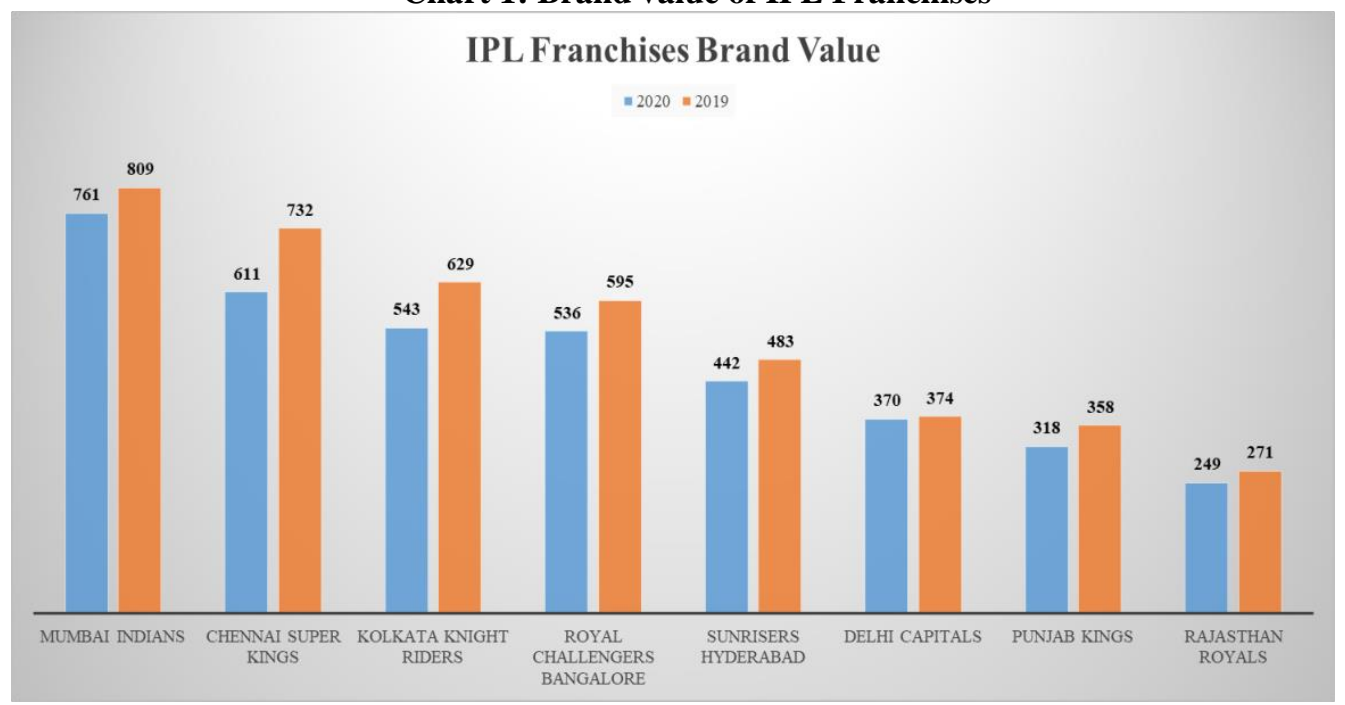

Broadcasting

Over time, the IPL has expanded tremendously and is now competing with the world's major sporting events for broadcasting rights.

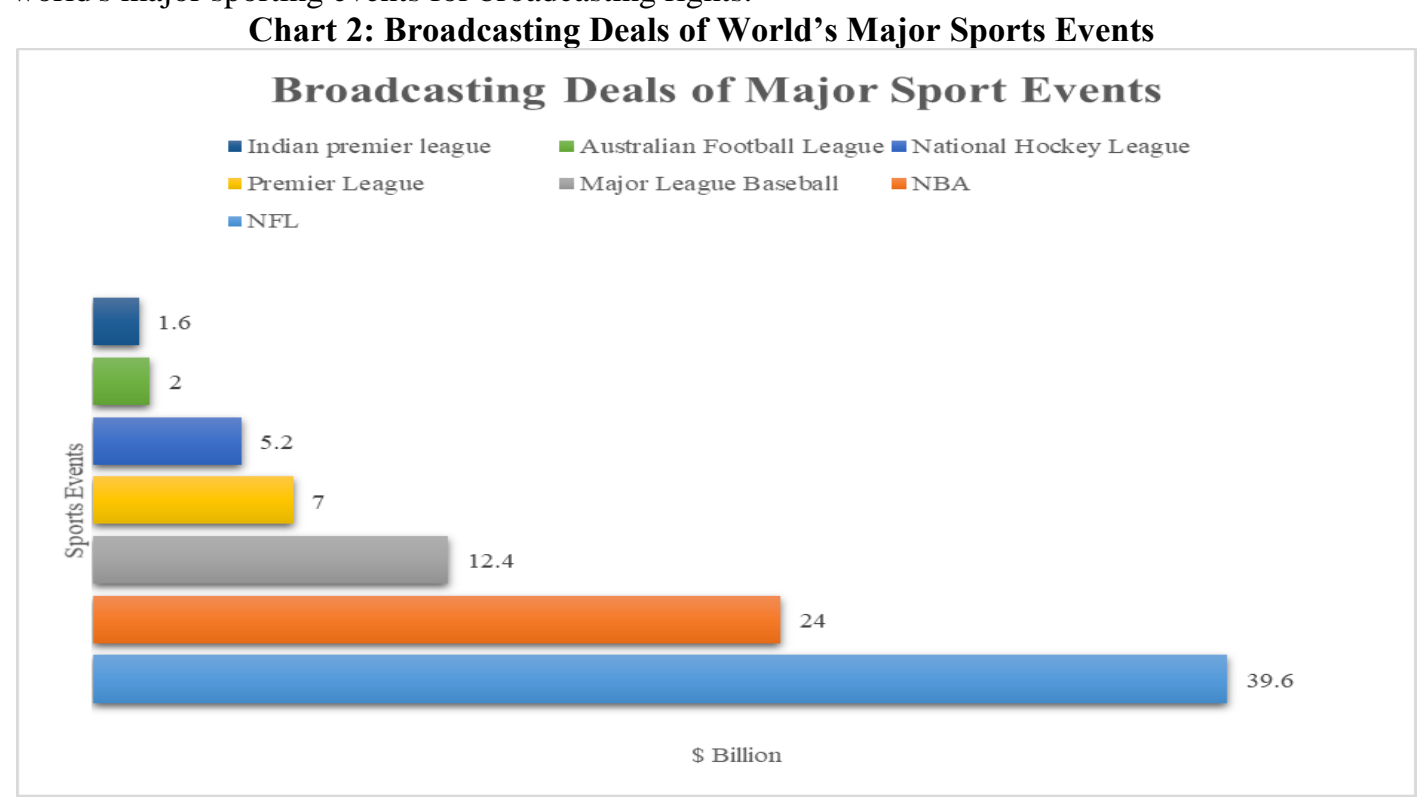

The broadcast rights to the IPL was a ten-year deal worth $\$ 1.03$ billion, were previously owned by collaboration between Sony Pictures Networks as well as World Sport Group. Domestic television will be handled by Sony, while international distribution would be handled by WSG. During 2008 to 2012, the original plan was for $20 \%$ of the revenues to go to the IPL, as $8 \%$ as a contribution for prize, and franchises can hold $72 \%$, with the IPL going public and listing its shares on the stock exchange after that. The IPL is now a big television product in India; mostly during competition, Sony MAX was often the most-viewed channel 
throughout the world, and overall framework income had surpassed $\$ 170$ million acquired just more than 1 billion impressions during the 2016 season, rising to 1.25 billion in 2017 . With a value of $\$ 2.55$ billion, Star India acquired the global rights for media to the IPL for a fiveyear term that starts from 2018, and this is the lavish television rights deal in cricket history. It is indeed a 158 percent increase over the prior agreement.

\section{Implications of Indian Premier League over the years}

\section{Macro-Level Implications}

The contribution of IPL to India's GDP is the most prominent macro factor. It was also revealed that during the IPL season, the tourism expands significantly, with a huge number of cricket fans from England, South Africa, and Australia. The cricketers themselves from these nations have to travel India every year to participate in the league with the dependents abd supporters that enhance sports tourism of the country. It thereby creates the jobs of various kinds during these months involves the demand for medical squad on all matches, cheerleaders of respective clubs, support staff, grounds men, and security personnel. In other words, it creates a large number of job openings in a variety of industries.

Another intriguing finding of the same survey was that the tier-2 cities have grown due to media concentration. IPL get a lot of media concentration because they take place all over India. As a result of the IPL's media concentration, Tier- 2 cities focussing more on infrastructure and growth, that would develop in tourism and its allied activities, and in turn an avenue for making returns for the region. In addition, with surging BCCI revenues, the tax contributions also rose up, and end up with higher revenue for government that shows a rough figure of Rs 3,500 crore as taxes during 2007-2008. Because it was deemed a benevolent organization, the BCCI did not pay taxes until the IPL. The authority of Income Tax declared the IPL as a commercial unit and charging BCCI Rs 350 crore per year since its beginning.

\section{Micro-Level Implications}

At a narrow stage, it's amazing to note the ways the BCCI makes money from the IPL through sponsorship, ticket sales, advertising, and broadcasting rights. In actuality, the IPL's five-year deal with Star India includes international broadcasting as well as digital rights, including a $\$ 510$ million annual fee. Star India contested against other bids for the IPL broadcasting rights, including Facebook. Each game costs $\$ 8.5$ million because the IPL is just 60 matches long and takes place over six weeks in April and May. On the other hand, Star India's huge viewership covers its costs and earns cash from commercial partnerships. The fact that cricket matches are played in a shorter format that usually lasts for three hours contributes to the high viewership.

Additionally, a substantial section of the viewership is middle-class, has a lot of discretionary income, and is of legal age of consent that is important because many sponsors have ties to breweries. During the IPL, there are a lot of beer commercials on television. The IPL team members gain money by selling products such as kits and jerseys, as well as from its sponsors. Members and clubs also profit through setting up of stalls in the stadiums and revenue shares revenues from the BCCI. The cricketers' earnings are determined by the price at which they are purchased during auctions. The money a player will make here is always greater than the money he or she might make playing for the national teams. This factor made the players focus on IPL that playing for their nations, which is evident. 


\section{The Economics of IPL in Brief}

\section{Significant rise in GDP}

The contribution granted by Indian Premier to the country's GDP is quite significant. A consistent increase in GDP has been attributed to large-scale branding, fanatical fan support, and a big worldwide fan following. The 60-day competition raked in INR 11.5 billion, according to a KPMG poll (USD 182 million).The BCCI had commissioned the KPMG Sports Advisory Group to conduct the survey.

\section{Boosts Tourism}

Apart from the 32 foreign players, international tourism income has increased dramatically. The IPL culminated in a 30 percent increase in travel income, according to Cox $\&$ Kings. During the IPL, cricket fans around the world would visit various states and cities. World Economic Forum published a survey that ranked the most appealing travel destinations, where India 11th in the Asia Pacific region and 34th overall.

Generates New Jobs

The Indian Premier League contributes significantly to India's economic growth by creating a big number of jobs. Corporations, their investors, sports stars, aspiring athletes, and others all help to create jobs. IPL generated \$3.2 billion in economic value as per the study of UN General Assembly for Peace and Development, and the demand for sports goods and applications has also improved predominantly, reaching 40 billion INR.

Media Exposure and Viewership

Economic Times of India stated that all previous records in terms of viewership were broken by 2019 season. This led to the surge in sponsorship from reputed global organisations comprising Coca-Cola, Maruti Suzuki, PhonePe, MRF, and others.

\section{Cultural Diversity}

During the IPL season, there is a lot of social media frenzy and much more events will take place as fans around the globe would visit the nation. In the cities hosting the T20 matches, there are several after-parties and activities. Foreign visitors from Bangladesh, Australia, Canada, Sri Lanka, England, and other countries arrive to take advantage of the festive season.

\section{Hotel \& Restaurant Business}

During every season, there would be a surge in travel, lodging, and eating projects. During the 60-day tournament, the number of check-ins increases and visitors from all over the world enjoy trying out different Indian cuisines.

\section{Increase in Tax Contribution}

BCCI was never required to pay taxes since it was considered a voluntary organization until the inception of IPL. After the commencement of IPL, it has been placed under commercial scanner, and BCCI has been forced to pay taxes that result in increased revenue to government.

\section{Conclusion}

In India, cricket rather more than just a sport, it as a full-fledged festival, celebrated with enormous liveliness and exhilaration. The Indian Premier League begun by the BCCI in 2008, and it has since grown to be one of the most successful and fast-paced events in cricket. The money-spinning fun filled event is a massive entertainer comprising of various economic 
concepts such as acquisitions, brand strategies, and economic development, among others. Over the past 12 years, the cricket competition has earned numerous awards and recognition, and it continues to do so with a growing economy. To summarize, the IPL influences the Indian economy as well as the lives of a diverse group of people. The tournament has created jobs worldwide and has emerged as one of the principal and most fashionable sports events, with gatekeepers, managing staff, groundskeepers, players, coaches, and staff, among others.

\section{References}

[1] Amit Gupta (2009), "India and the IPL: Cricket's Globalized", The Round Table Vol. 98, No. 401, 201-211, April 2009

[2] Shashi Kadapa (2013), "How sustainable is the strategy of the Indian Premier League -IPL? A critical review of 10 key issues that impact the IPL Strategy", International Journal of Scientific and Research Publications, Volume 3, Issue 12, December 2013

[3] Umar Rashid Dar (2016), "Indian Premier League- Boon or Bane", IOSR Journal of Sports and Physical Education (IOSR-JSPE) Vol. 3, Issue 6, PP 01-04, Nov. - Dec. 2016.

[4] Hemanta Saikia and Dibyojytoi Bhatta- Charjee, On classification of All-rounder's of the Indian Premier League (IPL): A Bayesian Approach, Vikalpa, 36(4), October - December, 2011, 51-66.

[5] https://thesportsschool.com/impact-of-ipl-on-indian-economy/

[6] Chandralekha Bhogadi (M20MS020) @ The Twisted Whisper OCT 04, 2020,

[7] https://timesofindia.indiatimes.com/readersblog/the-twisted-whisper/the-economics-of-ipl-26767/

[8] IPL: Boon or Bane to Cricket? www.Carerride.com Retrieved on 15 June, 2016 from http://www.careerride.com/view. aspx?id=24128.

[9] Miracle in Cricket history: Indian Premier League, Merinews, 23 April, 2008 Retrieved on 29 June, 2016 from http://ww.merinews.com/article/miracle-in-Cricket-historyindian-premierLeague/132943.shtml. 